\title{
Identification of the main active ingredients of agrochemicals used around the Lake of Tota, Colombia
}

\section{Identificación de los principales ingredientes activos de los agroquímicos usados en el entorno del Lago de Tota, Colombia}

Fecha recepción: 9 de agosto de 2015

Fecha aceptación: 7 de diciembre de 2015
Wilson Javier Pérez-Holguín ${ }^{1}$ Isnardo Antonio Grandas-Rincón ${ }^{2}$ Lizeth Natalia Ramírez-Acevedo ${ }^{3}$

Nixon Hernán Torres-Barrera ${ }^{4}$

\begin{abstract}
This paper presents a descriptive study aimed at identifying the main active ingredients, frequency of use, and the processes employed in the application of the agrochemicals most used around the Lake of Tota, which is considered the most important freshwater ecosystem in Colombia. A key source for this study is a survey to farmers, which sampling frame was established from a Geographical Institute Agustin Codazzi (IGAC) digital map, considering only the plots with some agricultural activity and runoff into the lake. This information was supplemented with geographic data obtained from Google Maps ${ }^{\circledR}$. As control mechanism, two additional sources were used: $i$ ) a manual count of packaging of agrochemicals in a certified collection center, and ii) a census of stores that supply such products in the study area. The results allow knowing the set of agrochemicals most used around the lake, their active ingredients, and the most common farming practices, some of which could entail some risk to farmers, consumers and the environment.
\end{abstract}

Keywords: agriculture; environmental impact; land use; pollution; Tota Lake; water management.

1 Ph.D. Universidad Pedagógica y Tecnológica de Colombia (Sogamoso, Colombia).wilson.perez@uptc.edu.co.

2 Esp. Universidad Pedagógica y Tecnológica de Colombia (Sogamoso, Colombia). isnardo.grandas@uptc.edu.co.

3 Universidad Pedagógica y Tecnológica de Colombia (Sogamoso, Colombia). lizeth.ramirez@uptc.edu.co.

4 Universidad Pedagógica y Tecnológica de Colombia (Sogamoso, Colombia).nixon.torres@uptc.edu.co. 


\section{Resumen}

Este trabajo presenta un estudio descriptivo encaminado a identificar los principales ingredientes activos, frecuencia de uso y procesos empleados en la aplicación de los agroquímicos más utilizados en el entorno del Lago de Tota, que es considerado el ecosistema de agua dulce más importante de Colombia. Una fuente clave para este estudio es una encuesta a los agricultores, cuyo marco muestral fue establecido a partir de un mapa digital del Instituto Geográfico Agustín Codazzi (IGAC), considerando solo los lotes con alguna actividad agrícola y escorrentía en el lago. Esta información fue complementada con datos geográficos de Google Maps $^{\circledR}$. Como mecanismo de control se utilizaron dos fuentes adicionales: i) un conteo manual de empaques de agroquímicos en un centro de recolección de certificado, y ii) un censo a los almacenes que suministran dichos productos en el área de estudio. Los resultados permitieron conocer los agroquímicos más utilizados alrededor del lago, sus ingredientes activos y las prácticas agrícolas más comunes, algunas de las cuales podrían implicar algún riesgo para los agricultores, los consumidores y el medioambiente.

Palabras clave: agricultura; contaminación; impacto ambiental; Lago de Tota; manejo del agua; uso de la tierra. 


\section{Introduction}

Given that agriculture is one of the most common activities in the vicinity of water sources, and the need for ever more and more agrochemicals for good harvests, there is a clear need for better and more updated information about agrochemical products that are being used around the lakes and other water bodies, in order to have improved tools to evaluate their potential impact on the quantity and quality of water.

The study system in this work is the Lake of Tota, which is the largest natural freshwater reserve in Colombia, with an area of $55 \mathrm{~km}^{2}$ and approximately $13.5 \%$ of the water available nationwide. Also, it is the second highest navigable lake in South America after Lake Titicaca. The Lake of Tota is located in the Department of Boyacá, 200 $\mathrm{km}$ northeast of Bogotá, at an elevation of $3015 \mathrm{~m}$, and constitutes the main source of water for about 250,000 people (Figures 1 and 2).

The Lake of Tota basin is part of the municipalities of Aquitania, Tota and Cuitiva (1). The largest urban center in its catchment area is Sogamoso, with a population of around 150,000 inhabitants. The main socio-economic activities carried out in the Lake of Tota and its environs are farming, fish-farming, livestock and tourism (2). The sum of all these activities generates a high demand for water, which is taken entirely from the lake. There is also a growing demand for water in the region for human consumption due to the rapid population growth in Sogamoso city and the surrounding towns.

Previous studies such as CONPES 3801 in 2014 (1) and the First Census of the Green Onion Crop, Region Lake of Tota DANE 2001 (2), show that the predominant crop in this zone is the green onion (Allium fistulosum), with about $96 \%$ of the cultivated area, and that this activity has been continuously performed for at least the past 50 years.

According to (1), the municipality of Aquitania contributes with near $80 \%$ of the national production of green onion, and generates annually revenues of around 96.3 million dollars (1US dollar $=3115.3$ Colombian pesos, 03/06/2016) for this product.

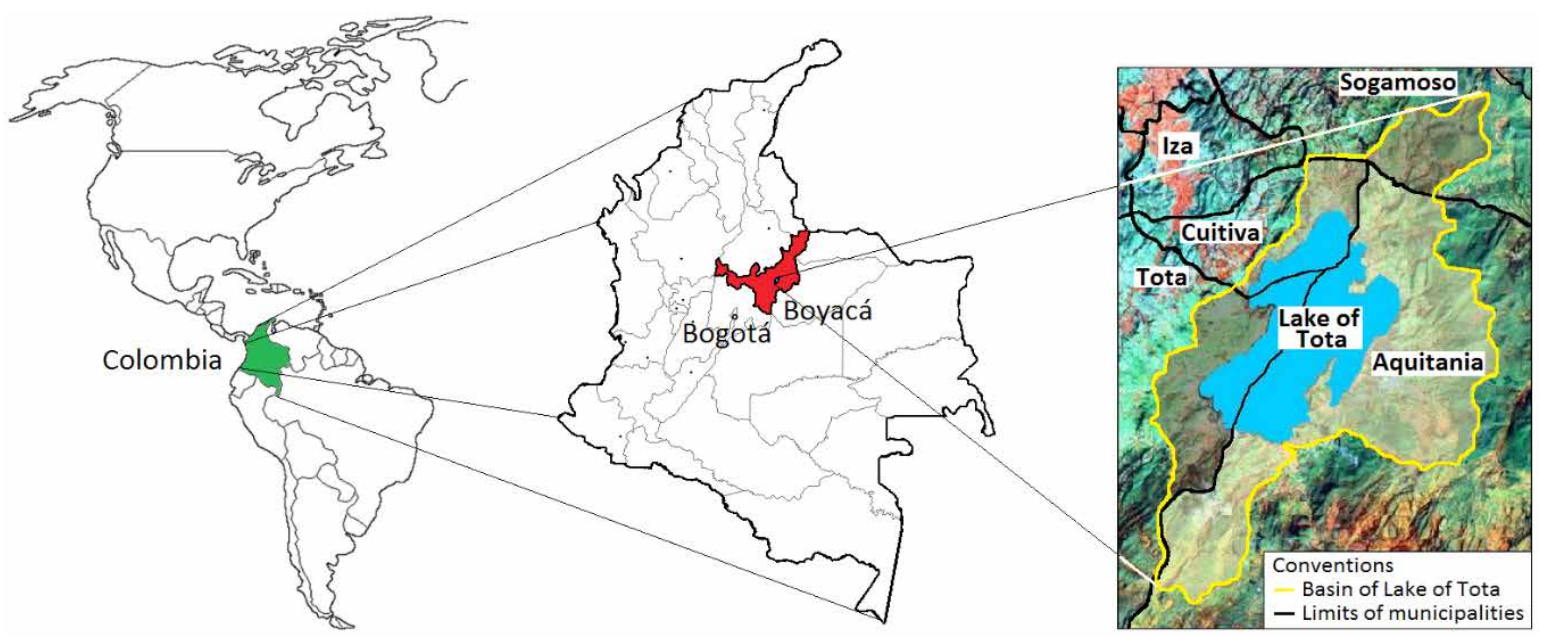

Figure 1. Location of the Lake of Tota. 


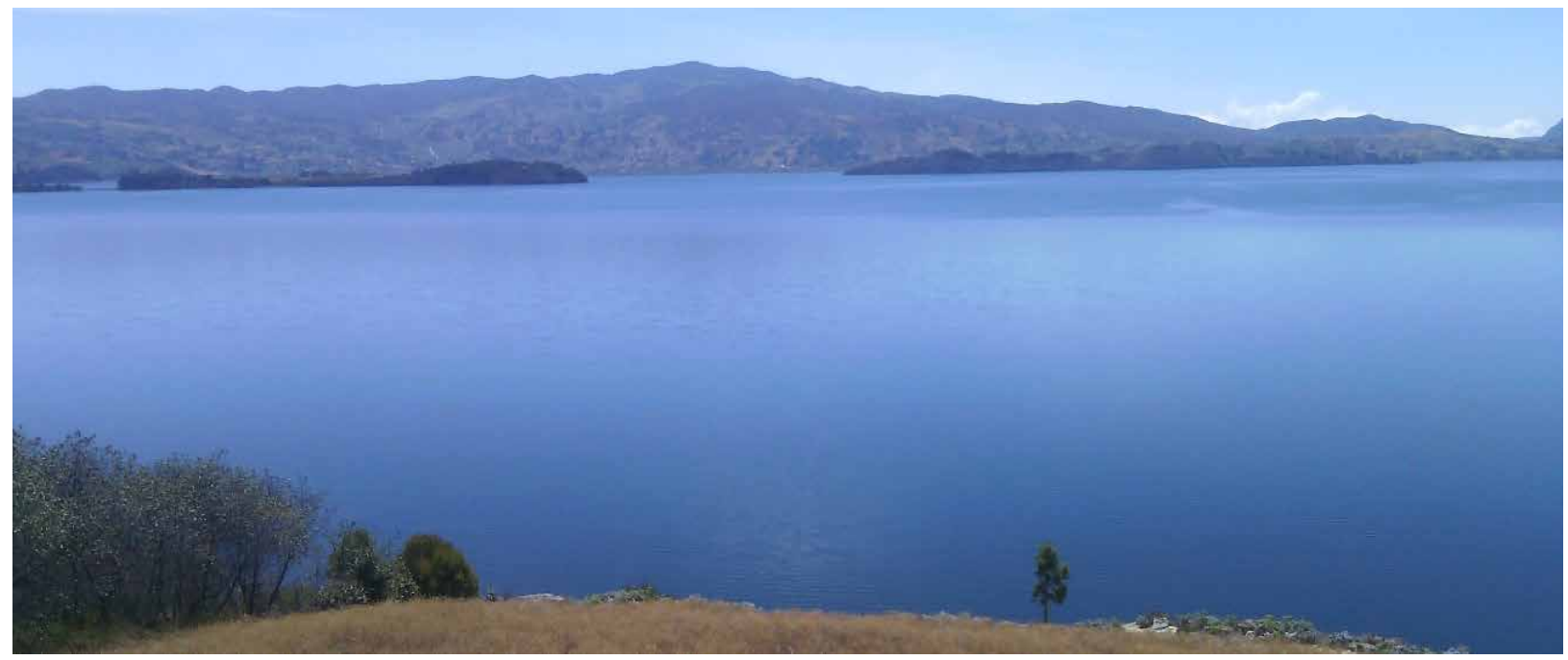

Figure 2. Panoramic of the Lake of Tota.

Despite the economic benefits provided by the green onion, it is important to take into account that this crop requires large amounts of water, along with the application of several fertilizers for its development and continuous production. Additionally, this kind of onion is susceptible of numerous diseases, pests, and weeds, making it necessary applying further agrochemicals such as fungicides, pesticides and herbicides (3).

Aware of the importance of the Lake of Tota for the region sustainability, several society sectors are concerned about its preservation and conservation, particularly because the designation of the Lake of Tota as one of the most threatened ecosystems on the globe, granted by mean of the "Grey Globe" award, from the World Wetland Network (WWN) in July 2012 (4). Although there are several environmental regulations worldwide such as (5)-(11), among others, and the governments have established a number of entities responsible for the implementation of policies, plans and programs on the environmental subject, not always these regulations are effectively enforced. Some studies dealing with problems related to the management of lakes and water conservation are for example (12) and (13), in which the authors describe the chronic overexploitation of water and the strong depletion of groundwater in China. Likewise, (14) presents disturbing data about the annual increase demand of water consumption projected from 2005 to 2030 worldwide.

An effective tool for the preservation and conservation of lakes is to perform continuous monitoring of the water quality and potential contaminants. In this context, (15) describes the use of a database to collect, manage and analyze environmental data for Poyang Lake in China. The work presented in (16) proposes a methodology to deal with sampling uncertainty for the monitoring of lakes, developed on Paladru Lake in France. Other studies like $(17,18)$, explore the use of satellite images as a mechanism for lakes monitoring, which is a very effective and widely used technique. Agricultural surveys are another method to investigate the current state of water resources. The agricultural surveys with multiple sampling frames proposed by FAO in 1996 (19) and 1998 (20) constitute a valuable source to design agricultural surveys; similarly, (21) and (22) described two methods for collecting data in agricultural censuses and surveys (known as area frames and list frames), along with its main advantages and disadvantages.

The Lake of Tota has been studied by universities, government entities, the private sector and social groups. For instance, the study developed by Pontificia Universidad Javeriana (PUJ) and Corpoboyacá in 2005 (23) describes many of the problems still persisting nowadays in the lake, such as water pol- 
lution by the use of agrochemicals, the improper disposal of sewage, the use of chicken manure as the main fertilizer for crops, and the deforestation in the upper basin, among others. In (24), the authors study the space-time determination of the phosphorus concentration in the Lake of Tota, between July and November of 2003. In (25), the authors describe the implementation of five stations to get data samples from the soil, arranged to better understand the effect of the rill Los Pozos in a specific area of the Lake of Tota. In (26), the authors evaluated the movement of pesticides to the Lake of Tota by analyzing water and suspended sediments samples for seven months; and found high to very high risk of surface water contamination in this lake. The authors in (27) surveyed the area of the Lake of Tota and found evidence of the intensive use of pesticides such as propineb, profenofos, deltamethrin and carbofuran. Likewise, the authors of this study have conducted a mass balance and further research to integrate dynamic parameters like the degradation and frequency rates.

The motivation for this work is having more and better information about the Lake of Tota, in order to contribute to its preservation and conservation by identifying potential contaminants of water due to agricultural activity. This study is based on the results of the final degree project introduced in (28), and presents the results of a descriptive study focused on identifying the main agrochemicals used around the Lake of Tota, its active ingredients, concentrations, frequency of use, and the predominant processes for its application. The results of this study will be used as input for the development of several projects, including some aimed at the use of technological solutions for the online monitoring of variables that may guarantee the quality of lake water.

Initially, this paper presents a briefly revision of some previous studies (section 2), followed by a description of the methods used for sampling and statistical analyses (section 3), the results and discussion (section 4), and finally the conclusions (section 5).

\section{Methods}

The approach used in this study exploits different sources of information in order to both, define the study area, and gather and contrast the collected information. Initially, the area frames method is used to define the target population; then, a survey to farmers is applied to gather the core data; and finally, this information is contrasted with the information obtained from a census to local farm stores, and a manual counting of agrochemical packages.

Taking into account the large size of the Lake of Tota basin, which is approximately 223,000 ha (1), the area of interest for this study was limited to the plots (or land areas) that potentially have a larger effect on the lake water quality due to the application of agrochemicals employed in the course of farming activities. To do this, the study area was limited to the plots that meet three previously defined filters: $i$ ) proximity to the lake border between 0 and $2 \mathrm{~km}$, ii) evidence of some kind of agricultural activity, and iii) runoff into the lake. These filters were manually applied following the area frames methodology, using a digital map from the Geographical Institute of Colombia (Instituto Geográfico Agustín Codazzi IGAC), along with geographical information obtained from satellite imagery taken from Google Maps ${ }^{\circledR}$ (Figures 3 and 4). The plots meeting the three filters were tabulated into a worksheet file, including an identification code, geographic location, and acreage (in $\mathrm{m}^{2}$ ) for each one. As a result, the study area was reduced from 223,000 ha to $2,331.8$ ha, which correspond to 7760 plots, and constitutes the target population for this study (Figure 5). 


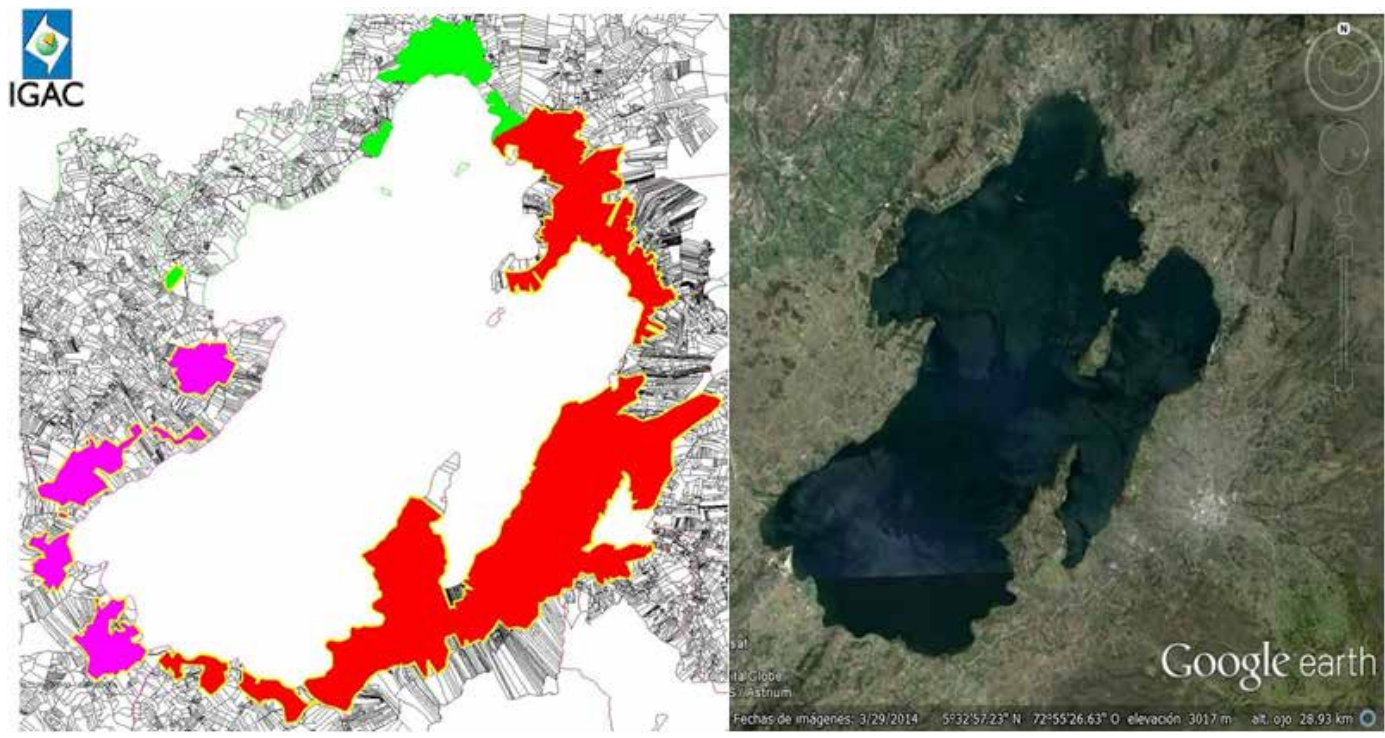

Figure 3. Map of the target population. The zones in magenta, red and green represent the plots with some kind of agricultural activity and runoff into the lake, for the municipalities of Tota, Aquitania and Cuitiva, respectively. This map was obtained by combining information from an IGAC digital map and a satellite image from Google Earth ${ }^{\circledR}$.
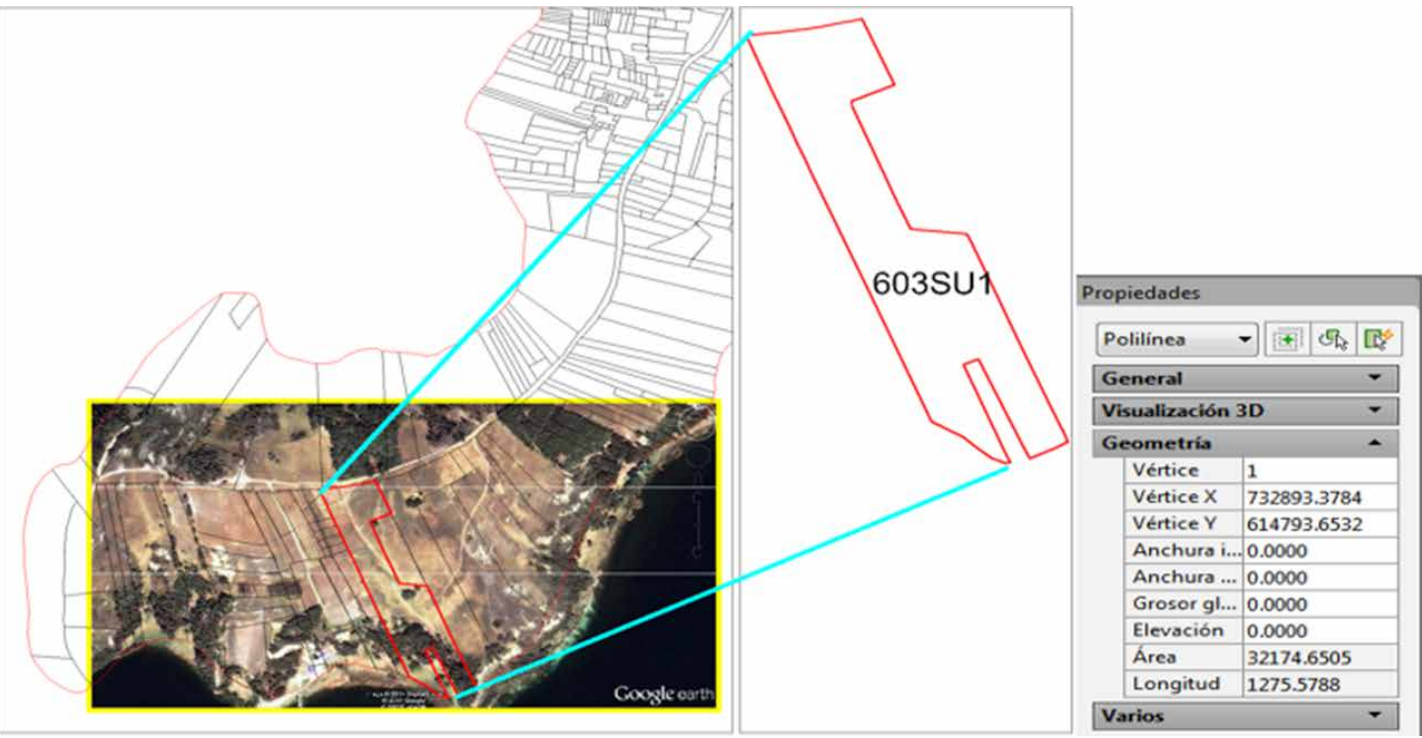

Figure 4. Example of the identification of plots of the sample by the matching process between the IGAC farm map and satellite images of Google Earth ${ }^{\circledR}$.

Subsequently, the farmers were surveyed between March and April of 2014. This survey aimed at collecting data to establish the list of agrochemicals more frequently used around the Lake of Tota, its frequency of use, and the predominant processes for its application. To determine the sample for this study, the high variability of the plots acreage making up the target population was considered. Therefore, the population was divided in percentiles, and these, in turn, were uniformly grouped in independent segments considering the variance as the main parameter for grouping them. This 
process resulted in 26 independent segments, on which the systematic random sampling technique was used to obtain the final sample for this survey using as parameters $z=95 \%$ and $e=5 \%$. The final sample size was 475 (h-definitive) land parcels or plots, which are equivalent to acreage of 335.7 ha. In order to facilitate the data collection, interviewers were provided with the previously obtained geo-referenced data of the plots composing the sample.
The final survey format was an iterative process, in which some exploratory surveys were applied to determine the predominant crops in the study area and its production cycles, as well as to approximate the list of agrochemicals employed during planting, development, and harvesting. From this information, the format was continuously adjusted, including new variables no previously considered, and clarifying some others.

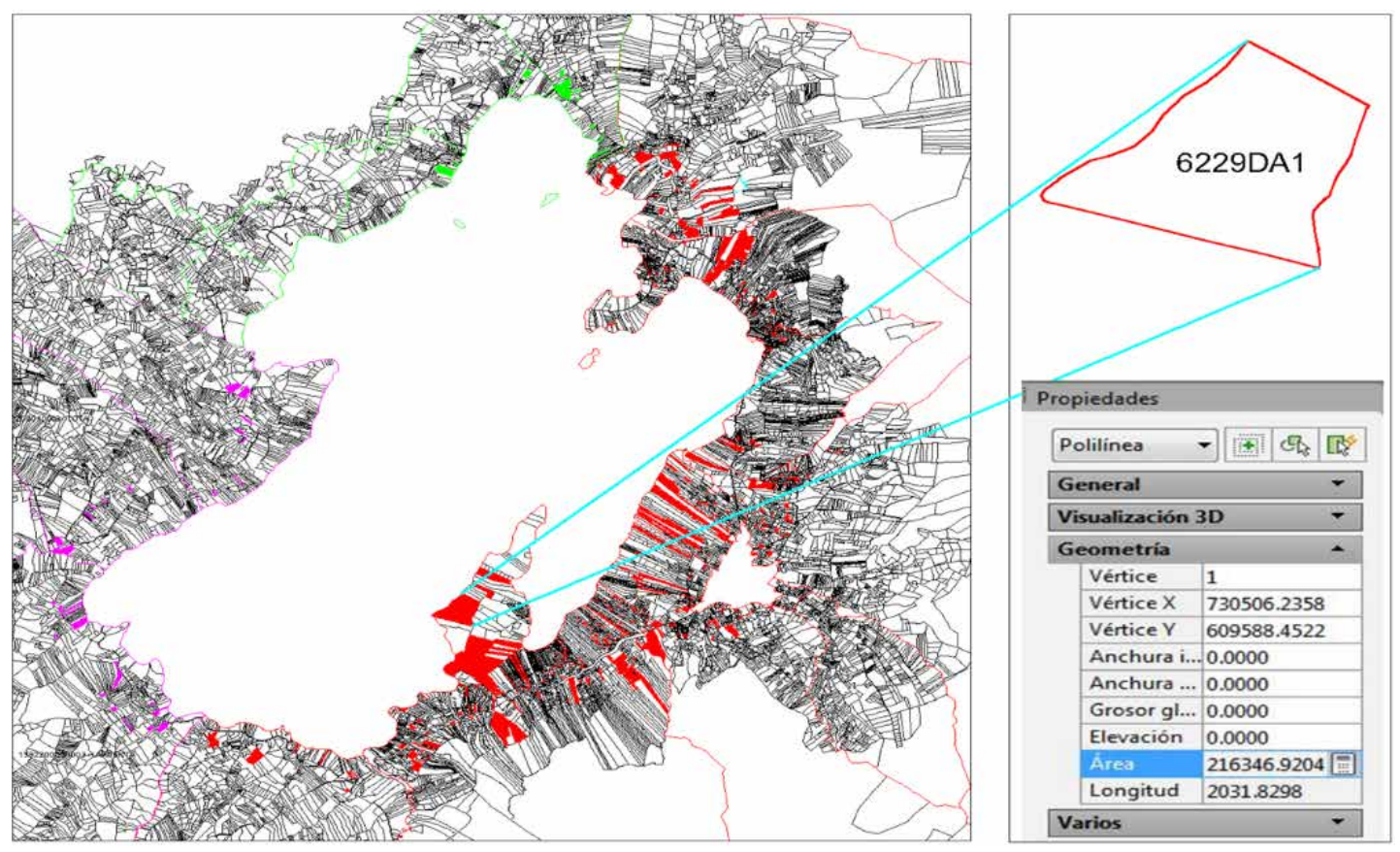

Figure 5. Map of the sampled area. The highlighted lots represent the final sample for the survey of farmers, together with its geographical location on a satellite image, for the three municipalities in the study zone.

The final survey format included five modules called: 1) 'Location of the land parcel' with nine variables; 2) 'Characteristics of the land parcel' with 35 variables; 3) 'Green onion crop' with 103 variables; 4) 'Other crops with 166 variables; and 5) 'Manage of substances and packages' with 12 variables. The total number of variables included in this survey was 325 .

As mentioned before, two additional primary sources were employed as a control mechanism in this study. Such sources were a census of stores that supply agrochemicals in the study area, and a manual counting of agrochemical packages. A list of agricultural stores in the zone of the Lake of Tota was obtained from the Chamber of Commerce of Sogamoso (CCS). Thus, a total of 14 stores located in the three municipalities nearest the lake (i.e., Aquitania, Tota and Cuitiva) were identified. Owners of local stores were asked about the commercial trademarks of the best-selling agrochemicals, including fungicides, fertilizers, and co-adjutants, as well as on its sales quantities. With this information, a preliminary list of active agents for each product was obtained. In addition, a manual counting of packages was performed taking into account the Colombian regulations, which make mandatory for farmers collect the empty packages 
and containers of agrochemicals, and properly disposing them in a certified collection center, which is the Campolimpio Corporation in this case (29). Usually, this collection center gathers about $1 \mathrm{t}$ month of agrochemical packages, which are incinerated in the furnace of a local cement producer company without any special registration or control about trademarks or active ingredients of such products. The counting activity was carried out by six people in two work days. Collected information through this activity allowed to extend the list of agrochemicals employed in the study area, and to have a better approximation to the real amounts of use of such products. Finally, the data collected were systematized using SPSS statistical software, from which a database was implemented both in SPSS and Microsoft Excel.

\section{Results and discussion}

Only $51.8 \%$ of the sampled area was effectively cultivated at the time of this study, corresponding to 173.89 ha. Of cultivated area, the $93.1 \%$ is located in Aquitania, and the remaining $6.9 \%$ is distributed among the municipalities of Tota and Cuitiva.

The following are some important aspects of the green onion cultivation that were observed from the survey to farmers:

- The green onion is the predominant crop found around the Lake of Tota covering 93.9\% of the cultivated area; it should be noted that this value is similar to that reported by DANE in 2001 for the municipality of Aquitania (2).

- On average, the process of cultivating green onions involves a period of 12 months. In this period, three harvests are obtained: the first one at 6 months after planting, and two further harvests, one every 3 months.

- The raw chicken manure is used by $96 \%$ of farmers of green onion as organic fertilizer. It is used at the beginning of the first and third harvests, using in average $39.61 \mathrm{t} / \mathrm{ha}$ in each case, thereby applying near to 80 t/ha in a year.
- Similarly, the survey to farmers revealed the following issues regarding the manipulation of agrochemicals:

- $\quad 74 \%$ of farmers said they have never received proper training about the safe use of agrochemicals, while only $26 \%$ said they had received an adequate training in this regard by representatives of manufacturers.

- A common practice among farmers of green onion is to mix three or more agrochemical products in a single application. From this mixture a solution is obtained, usually called 'cocktail', which may contain water as solvent, fungicides, fertilizers, bio-stimulants (or hormones), adjutants (also called 'glue'), and insecticides.

- Farmers said they mix the agrochemicals to reduce the workload, but they admitted to not taking into account the agrochemicals' active ingredients or the manufacturers handling recommendations, and they do not ask for technical assistance.

- By observing the typical composition of a cocktail (for a single spray application), it was found that farmers include at least one fungicide $(100 \%$ of cases), one foliar fertilizer $(93 \%$ of cases), one adjuvant ( $83 \%$ of cases), and one insecticide $(69.3 \%$ of cases).

- $55.4 \%$ of the farmers use up to four different fungicides by harvest, with application intervals from 8 to 15 days, depending on the weather.

- Herbicides are annually applied, but these are not used in cocktails. $47.3 \%$ of farmers apply only one herbicide, while $5.6 \%$ applied two herbicides separately.

- According to farmers, the application of foliar agrochemicals depends on the weather, with frequencies as high as four times in a month during a rainy season, and only twice a month during a dry season (in Colombia occurs only two weather seasons, dry and rainy). 
- Regarding the agrochemical packages managing, $83 \%$ of farmers declared meeting the national regulations and procedures to collect and deliver the packages to the 'Campolimpio' Corporation, responsible for its proper processing and disposal. However, $17 \%$ of farmers recognized that they often burn or bury the agrochemicals packages in their own land parcels.

Combining all the information gathered from the three sources used in this study, it was found that around the Lake of Tota 183 agrochemicals are used, mainly for the green onion crop, which comprise 77 fungicides, 21 insecticides, 10 herbicides, 56 foliar fertilizers, 5 chemical fertilizers, 5 hormones and 9 adjutants. Tables I to VII list the most frequently used agrochemicals, ordered from the most to the least used. For each agrochemical, its Colombian trade name, active agents, concentration, dose, and toxicity, based on the technical specifications provided by manufacturers, are shown.

Table I. Fungicides most used around the Lake of Tota.

\begin{tabular}{|c|c|c|c|c|c|c|}
\hline Trade name & $\begin{array}{c}\text { Active } \\
\text { Ingredient } \\
\# 1\end{array}$ & $\begin{array}{c}\text { Concen- } \\
\text { tra- } \\
\text { tion }\end{array}$ & $\begin{array}{c}\text { Active } \\
\text { Ingredient \#2 }\end{array}$ & $\begin{array}{l}\text { Concen- } \\
\text { tra- } \\
\text { tion }\end{array}$ & Dose & $\begin{array}{c}\text { Toxicity } \\
\text { (EPA) }\end{array}$ \\
\hline ANTRACOL 70 WP & Propineb & $700 \mathrm{~g} / \mathrm{kg}$ & - & - & $1,5-2,5 \mathrm{~kg} / \mathrm{ha}$ & IV \\
\hline FITORAZ WP76 & Propineb & $700 \mathrm{~g} / \mathrm{kg}$ & Cimoxanil & $60 \mathrm{~g} / \mathrm{kg}$ & $0,5-1,0 \mathrm{~L} / \mathrm{ha}$ & III \\
\hline TRIVIA WP & Propineb & $667 \mathrm{~g} / \mathrm{kg}$ & Fluopicolide & $60 \mathrm{~g} / \mathrm{kg}$ & $40-60 \mathrm{~g} / 20 \mathrm{~L}$ & III \\
\hline FORUM $500 \mathrm{WP}$ & $\begin{array}{l}\text { Dimethomo- } \\
\text { rfh }\end{array}$ & $500 \mathrm{~g} / \mathrm{kg}$ & - & - & $\begin{array}{r}0,36-0,40 \mathrm{~kg} / \\
\mathrm{ha}\end{array}$ & III \\
\hline DITHANE M 45 WP & Mancozeb & $800 \mathrm{~g} / \mathrm{kg}$ & $\begin{array}{c}\text { Etilenbisditiocarba- } \\
\text { mato }\end{array}$ & $62 \mathrm{~g} / \mathrm{kg}$ & $\begin{array}{r}550-750 \\
g / 200 \mathrm{~L}\end{array}$ & III \\
\hline RHODAX $70 \mathrm{WP}$ & Fosetyl & $350 \mathrm{~g} / \mathrm{kg}$ & Mancozeb & $350 \mathrm{~g} / \mathrm{kg}$ & $2,0-2,5 \mathrm{~kg} / \mathrm{ha}$ & III \\
\hline $\begin{array}{l}\text { RIDOMIL GOLD MZ } \\
68 \mathrm{WP}\end{array}$ & Mancozeb & $640 \mathrm{~g} / \mathrm{kg}$ & Metalaxyl & $40 \mathrm{~g} / \mathrm{kg}$ & $2,5 \mathrm{~kg} / \mathrm{ha}$ & IV \\
\hline IMPETU MZ 690 WP & Mancozeb & $600 \mathrm{~g} / \mathrm{kg}$ & Dimetomorf & $90 \mathrm{~g} / \mathrm{kg}$ & $2,0 \mathrm{~kg} / \mathrm{ha}$ & IV \\
\hline MANZATE $200 \mathrm{WP}$ & Mancozeb & $800 \mathrm{~g} / \mathrm{kg}$ & - & - & $2,0-4,0 \mathrm{~kg} / \mathrm{ha}$ & III \\
\hline ELOSAL 720 SC & Sulfur & $720 \mathrm{~g} / \mathrm{L}$ & - & - & $0,75-1,0 \mathrm{~L} / \mathrm{ha}$ & III \\
\hline SCORE 250 EC & $\begin{array}{l}\text { Difeno- } \\
\text { conazol }\end{array}$ & $250 \mathrm{~g} / \mathrm{L}$ & - & - & $\begin{array}{r}500-600 \mathrm{~cm}^{3} / \\
\text { ha }\end{array}$ & II \\
\hline NATIVO SC & $\begin{array}{l}\text { Tebuco- } \\
\text { nazole }\end{array}$ & $200 \mathrm{~g} / \mathrm{L}$ & Trifloxystrobin & $100 \mathrm{~g} / \mathrm{L}$ & $0,4-0,5 \mathrm{~L} / \mathrm{ha}$ & III \\
\hline DACONIL 720 SC & $\begin{array}{l}\text { Chlorotha- } \\
\text { lonil }\end{array}$ & $720 \mathrm{~g} / \mathrm{L}$ & - & - & $350 \mathrm{~mL} / 200 \mathrm{~L}$ & II \\
\hline FOLICUR $250 \mathrm{EW}$ & $\begin{array}{l}\text { Tebuco- } \\
\text { nazole }\end{array}$ & $250 \mathrm{~g} / \mathrm{kg}$ & - & - & $0,8 \mathrm{~L} / \mathrm{ha}$ & IV \\
\hline AGUILA WG & Metiram & $700 \mathrm{~g} / \mathrm{kg}$ & - & - & $\begin{array}{r}400-750 \\
g / 200 L\end{array}$ & III \\
\hline
\end{tabular}


Table II. Insecticides most used around the Lake of Tota.

\begin{tabular}{lccccrc}
\hline \multicolumn{1}{c}{ Trade name } & $\begin{array}{c}\text { Active } \\
\text { Ingredient \#1 }\end{array}$ & $\begin{array}{c}\text { Concentra- } \\
\text { tion }\end{array}$ & $\begin{array}{c}\text { Active } \\
\text { Ingredient \#2 }\end{array}$ & $\begin{array}{c}\text { Concentra- } \\
\text { tion }\end{array}$ & Dose & $\begin{array}{c}\text { Toxicity } \\
\text { (EPA) }\end{array}$ \\
\hline MALATION 500 & Malathion & $604 \mathrm{~g} / \mathrm{L}$ & - & - & $1,0-2,0 \mathrm{~L} / \mathrm{ha}$ & III \\
C U R A C R O N & Profenofos & $500 \mathrm{~g} / \mathrm{L}$ & - & - & $1,5 \mathrm{~L} / \mathrm{ha}$ & II \\
500 EC & & $25 \mathrm{~g} / \mathrm{L}$ & - & - & $0,4-0,45 \mathrm{~L} / \mathrm{ha}$ & III \\
DECIS 5 EC & Deltametrina & $384 \mathrm{~g} / \mathrm{L}$ & - & - & $300 \mathrm{~cm} / \mathrm{ha}$ & III \\
KARATE & Permetrina & $50 \mathrm{~g} / \mathrm{kg}$ & - & - & $50 \mathrm{Kg} / \mathrm{ha}$ & III \\
FURADAN 5 G & Carbofuran & $141 \mathrm{~g} / \mathrm{L}$ & Lambdacialotrina & $106 \mathrm{~g} / \mathrm{L}$ & $400 \mathrm{~cm}^{3} / \mathrm{ha}$ & II \\
ENGEO & Tiametoxam & & & & &
\end{tabular}

Table III. Herbicides most used around the Lake of Tota.

\begin{tabular}{llcrc}
\hline \multicolumn{1}{c}{ Trade namek } & \multicolumn{1}{c}{$\begin{array}{c}\text { Active } \\
\text { Ingredient \# } 1\end{array}$} & $\begin{array}{c}\text { Concen- } \\
\text { tra-tion }\end{array}$ & Dose & $\begin{array}{c}\text { Toxicity } \\
\text { (EPA) }\end{array}$ \\
\hline ROUNDUP ACTIVO & Glyphosate & $480 \mathrm{~g} / \mathrm{kg}$ & $2,0 \mathrm{~L} / \mathrm{ha}$ & IV \\
GOAL & Oxyfluorfen & $240 \mathrm{~g} / \mathrm{kg}$ & $1,0-1,5 \mathrm{~L} / \mathrm{ha}$ & IV \\
\hline
\end{tabular}

Table IV. Foliar Fertilizers most used around the Lake of Tota (Applied in spray).

\begin{tabular}{|c|c|c|c|c|c|c|c|c|}
\hline Trade name & $\begin{array}{c}\text { Active } \\
\text { Ingredient } \\
\# 1\end{array}$ & $\begin{array}{c}\text { Concen- } \\
\text { tra- } \\
\text { tion }\end{array}$ & $\begin{array}{c}\text { Active } \\
\text { Ingredient } \\
\# 2\end{array}$ & $\begin{array}{c}\text { Concen- } \\
\text { tra- } \\
\text { tion }\end{array}$ & $\begin{array}{c}\text { Active } \\
\text { Ingredient \#3 }\end{array}$ & $\begin{array}{c}\text { Concen- } \\
\text { tra- } \\
\text { tion }\end{array}$ & Dose & $\begin{array}{c}\text { Toxicity } \\
\text { (EPA) }\end{array}$ \\
\hline CRECER 500 & Nitrogen & $420 \mathrm{~g} / \mathrm{kg}$ & Phosphorus & $30 \mathrm{~g} / \mathrm{kg}$ & Phosphorus & $30 \mathrm{~g} / \mathrm{kg}$ & $1 \mathrm{~kg} / 200 \mathrm{~L}$ & IV \\
\hline $\begin{array}{l}\text { COSMOFO- } \\
\text { LIAR }\end{array}$ & Nitrogen & $180 \mathrm{~g} / \mathrm{kg}$ & Phosphorus & $280 \mathrm{~g} / \mathrm{kg}$ & - & - & $1 \mathrm{~kg} / 200 \mathrm{~L}$ & IV \\
\hline $\begin{array}{l}\text { DESARROL- } \\
\text { LO }\end{array}$ & Nitrogen & $300 \mathrm{~g} / \mathrm{kg}$ & Phosphorus & $70 \mathrm{~g} / \mathrm{kg}$ & Phosphorus & $60 \mathrm{~g} / \mathrm{kg}$ & $1 \mathrm{~kg} / 200 \mathrm{~L}$ & IV \\
\hline $\begin{array}{l}W \cup X \quad A \quad L \\
\text { TAPA NEG- } \\
\text { RA }\end{array}$ & Nitrogen & $160 \mathrm{~g} / \mathrm{L}$ & Phosphorus & $160 \mathrm{~g} / \mathrm{L}$ & Phosphorus & $120 \mathrm{~g} / \mathrm{L}$ & $50 \mathrm{~mL} / 20 \mathrm{~L}$ & IV \\
\hline NUTRIMINS & Nitrogen & $200 \mathrm{~g} / \mathrm{L}$ & - & - & - & - & $4 \mathrm{~L} / \mathrm{ha}$ & IV \\
\hline OMEX K41 & Potassium & $410 \mathrm{~g} / \mathrm{L}$ & Magnesium & $25 \mathrm{~g} / \mathrm{L}$ & Sulfur & $160 \mathrm{~g} / \mathrm{L}$ & $1 \mathrm{~L} / \mathrm{ha}$ & IV \\
\hline $\begin{array}{l}\text { W } \cup X A \text { A } \\
\text { TAPA VERDE }\end{array}$ & Nitrogen & $160 \mathrm{~g} / \mathrm{L}$ & Magnesium & $30 \mathrm{~g} / \mathrm{L}$ & Calcium & $240 \mathrm{~g} / \mathrm{L}$ & $3-4 \mathrm{~L} / \mathrm{ha}$ & IV \\
\hline AMINO K3 & $\begin{array}{c}\text { Amino-ac- } \\
\text { ids } \\
\text { Peptides }\end{array}$ & $400 \mathrm{~g} / \mathrm{L}$ & Nitrogen & $70 \mathrm{~g} / \mathrm{L}$ & - & - & $2 \mathrm{~L} / \mathrm{ha}$ & IV \\
\hline KADOSTIM & Nitrogen & $50 \mathrm{~g} / \mathrm{L}$ & Amino-acids & $20 \mathrm{~g} / \mathrm{L}$ & - & - & $1 \mathrm{~L} / \mathrm{ha}$ & IV \\
\hline $\begin{array}{l}\text { NUTRIFOLI- } \\
\text { AR }\end{array}$ & Nitrogen & $200 \mathrm{~g} / \mathrm{L}$ & Potassium & $50 \mathrm{~g} / \mathrm{L}$ & - & & $2 \mathrm{~L} / \mathrm{ha}$ & IV \\
\hline URFOS 44 & Nitrogen & $17 \mathrm{~g} / \mathrm{L}$ & Phosphorus & $44 \mathrm{~g} / \mathrm{L}$ & - & & $\begin{array}{r}0,1-1 \mathrm{~kg} / 100 \\
\mathrm{~L}\end{array}$ & III \\
\hline
\end{tabular}


Table V. Chemical Fertilizers most used around the Lake of Tota (Edaphically applied).

\begin{tabular}{|c|c|c|c|c|c|c|c|c|}
\hline $\begin{array}{c}\text { Trade } \\
\text { name }\end{array}$ & $\begin{array}{c}\text { Active } \\
\text { Ingredient } \\
\mathbf{\# 1}\end{array}$ & $\begin{array}{c}\text { Concen- } \\
\text { tra- } \\
\text { tion }\end{array}$ & $\begin{array}{c}\text { Active } \\
\text { Ingredient \#2 }\end{array}$ & $\begin{array}{c}\text { Concen- } \\
\text { tra- } \\
\text { tion }\end{array}$ & $\begin{array}{c}\text { Active } \\
\text { Ingredient } \\
\mathbf{\# 3}\end{array}$ & $\begin{array}{c}\text { Concen- } \\
\text { tra- } \\
\text { tion }\end{array}$ & Dose & $\begin{array}{c}\text { Toxicity } \\
\text { (EPA) }\end{array}$ \\
\hline TRIPLE 15 & Nitrogen & $15 \%$ & $\begin{array}{c}\text { Available Phos- } \\
\text { phor }\end{array}$ & $15 \%$ & Potassium & $15 \%$ & $\begin{array}{c}200 \mathrm{~kg} / \\
\mathrm{ha}\end{array}$ & $\mathrm{IV}$ \\
\hline TRIPLE 18 & Nitrogen & $18 \%$ & $\begin{array}{c}\text { Available Phos- } \\
\text { phor }\end{array}$ & $18 \%$ & Potassium & $18 \%$ & $\begin{array}{c}200 \mathrm{~kg} / \\
\mathrm{ha}\end{array}$ & $\mathrm{IV}$ \\
\hline ABIMGRA & Calcium & $21,50 \%$ & Ashes & $55 \%$ & Silicon & $15,50 \%$ & $\begin{array}{c}200 \mathrm{~kg} / \\
\mathrm{ha}\end{array}$ & $\mathrm{IV}$ \\
\hline
\end{tabular}

Table VI. Hormones most used around the Lake of Tota.

\begin{tabular}{|c|c|c|c|c|}
\hline Trade name & $\begin{array}{c}\text { Active } \\
\text { Ingredient \#1 }\end{array}$ & $\begin{array}{l}\text { Concentra- } \\
\text { tion }\end{array}$ & Dose & $\begin{array}{c}\text { Toxic- } \\
\text { ity } \\
\text { (EPA) }\end{array}$ \\
\hline $\begin{array}{l}\text { P R O G I B B } \\
40 \% \text { GS }\end{array}$ & $\begin{array}{c}\text { Gibberellic } \\
\text { Acid }\end{array}$ & $10 \%$ & $10 \mathrm{~g} / 200 \mathrm{~L}$ & IV \\
\hline MARAX & $\begin{array}{l}\text { Gibberellic } \\
\text { Acid }\end{array}$ & $10 \%$ & $8,0-16 \mathrm{~g} / 200$ & IV \\
\hline ERGOSTIM & $\begin{array}{c}\text { Gibberellic } \\
\text { Acid }\end{array}$ & $5 \%$ & 0,6 L/ha & IV \\
\hline
\end{tabular}

Table VII. Adjutants most used around the Lake of Tota.

\begin{tabular}{|c|c|c|c|c|c|c|}
\hline Trade name & $\begin{array}{c}\text { Active } \\
\text { ingredient \#1 }\end{array}$ & $\begin{array}{l}\text { Concen- } \\
\text { tra-tion }\end{array}$ & $\begin{array}{c}\text { Active } \\
\text { Ingredient \#2 }\end{array}$ & $\begin{array}{l}\text { Concen- } \\
\text { tra-tion }\end{array}$ & Dose & $\begin{array}{c}\text { Toxicity } \\
\text { (EPA) }\end{array}$ \\
\hline $\begin{array}{l}\text { AGROTIN } \\
\text { SL }\end{array}$ & $\begin{array}{l}\text { Polysaccharides, polyvinyl alco- } \\
\text { hols, nonylphenols, silicones }\end{array}$ & $79,45 \mathrm{~g} / \mathrm{L}$ & - & - & $1-2 \mathrm{~L} / 200 \mathrm{~L}$ & III \\
\hline PEGAL PH & $\begin{array}{c}\text { Ethanol polyethoxylated nonyl } \\
\text { phenol }\end{array}$ & $335 \mathrm{~g} / \mathrm{L}$ & $\begin{array}{l}\text { Alkyl phenol } \\
\text { Polyglycol }\end{array}$ & $315 \mathrm{~g} / \mathrm{L}$ & $1 \mathrm{~cm}^{3} / \mathrm{L}$ & IV \\
\hline MIXEL TOP & Alkyl aryl polyether alcohol & $250 \mathrm{~g} / \mathrm{L}$ & - & - & $\begin{array}{r}100-500 \mathrm{~cm}^{3} / 100 \\
\mathrm{~L}\end{array}$ & III \\
\hline $\begin{array}{l}\text { COSMO IN } \\
\text { D }\end{array}$ & Alcohol Ethoxylate & $16 \mathrm{~g} / \mathrm{L}$ & $\begin{array}{c}\text { Alkyl ether } \\
\text { polyoxiethyle- } \\
\text { ne }\end{array}$ & $10,85 \mathrm{~g} / \mathrm{L}$ & $100 \mathrm{~cm}^{3} / 100 \mathrm{~L}$ & III \\
\hline
\end{tabular}


Tables VIII to XIV show the actual quantities used of each active ingredient of the agrochemicals listed above. This information was obtained from the three primary sources employed in this work according to Equation 1, where, is the total amount of the active agent, is the total number of agrochemicals used in the study zone, is the total amount of the agrochemical product, and is the concentration of the active ingredient in the agrochemical.

Table VIII. Agent Active Fungicides kg/month.

\begin{tabular}{lrrr}
\hline \multicolumn{1}{c}{ Active } & \multicolumn{1}{c}{$\begin{array}{c}\text { Survey to } \\
\text { Farmers }\end{array}$} & $\begin{array}{c}\text { Counting } \\
\text { of Pack- } \\
\text { ages }\end{array}$ & $\begin{array}{c}\text { Census } \\
\text { to Local } \\
\text { Stores }\end{array}$ \\
\hline Propineb & 719,82 & 832,38 & 1978,73 \\
Mancozeb & 202,54 & 498,89 & 1160,2 \\
D i m e th o- & 136,29 & 77,7 & 216,78 \\
morfh & 53,64 & 84,24 & 397,44 \\
Sulfur & 25,17 & 0 & 0 \\
Fosetyl & 0 & 57,2 & 0 \\
Folpet & 21,51 & 34,33 & 90 \\
Cymoxanil & & & \\
\hline
\end{tabular}

Table IX. Agent Active Insecticides kg/month.

\begin{tabular}{lrrr}
\hline \multicolumn{1}{c}{ Active Agent } & $\begin{array}{c}\text { Survey to } \\
\text { Farmers }\end{array}$ & $\begin{array}{c}\text { Counting of } \\
\text { Packages }\end{array}$ & $\begin{array}{c}\text { Census to } \\
\text { Local Stores }\end{array}$ \\
\hline Malathion & 46,48 & 135,296 & 161,27 \\
Profenofos & 34,52 & 5,25 & 51,63 \\
Deltamethrin & 0,77 & 1,8 & 0 \\
Carbofuradan & 0,7 & 0 & 126,24 \\
Lambda - cyha- & 0,34 & 0,05 & 0 \\
lothrin & & & \\
Methamidophos & 0 & 0,25 & 58,60 \\
Thiamethoxam & 0,16 & 0 & 47,39 \\
\hline
\end{tabular}

Table X. Agent Active Herbicides kg/month.

\begin{tabular}{lrrr}
\hline Active Agent & $\begin{array}{c}\text { Survey to } \\
\text { Farmers }\end{array}$ & $\begin{array}{c}\text { Counting of } \\
\text { Packages }\end{array}$ & \multicolumn{2}{c}{$\begin{array}{c}\text { Census to } \\
\text { Local Stores }\end{array}$} \\
\hline Glyphosate & 9,07 & 0,48 & 42,54 \\
Oxyfluorfen & 0,75 & 2,4 & 8,64 \\
Paraquat & 0 & 1,4 & 35 \\
Metribuzin & 0 & 0 & 2,64 \\
\hline
\end{tabular}


Table XI. Agent Active Foliar Fertilizers kg/month.

\begin{tabular}{lrrr}
\hline \multicolumn{1}{c}{ Active Agent } & $\begin{array}{c}\text { Survey to } \\
\text { Farmers }\end{array}$ & $\begin{array}{c}\text { Counting of } \\
\text { Packages }\end{array}$ & \multicolumn{1}{c}{$\begin{array}{c}\text { Census to } \\
\text { Local Stores }\end{array}$} \\
\hline Nitrogen & 160,43 & 80,524 & 652,73 \\
Potassium & 78,88 & 57,55 & 163,77 \\
Phosphurus & 50,44 & 30,97 & 181,18 \\
Amino peptides & 41,62 & 0 & 35,53 \\
Sulfur & 18,30 & 16,64 & 27 \\
Magnesium & 29,11 & 4,45 & 20,82 \\
\hline
\end{tabular}

Table XII. Agent Active Chemical Fertilizers kg/month.

\begin{tabular}{lrrr}
\hline \multicolumn{1}{c}{ Active Agent } & $\begin{array}{c}\text { Survey to } \\
\text { Farmers }\end{array}$ & $\begin{array}{c}\text { Counting of } \\
\text { Packages }\end{array}$ & $\begin{array}{c}\text { Census } \\
\text { to Local } \\
\text { Stores }\end{array}$ \\
\hline Nitrogen & 13565 & 0 & 3369 \\
Potassium & 13565 & 0 & 4880 \\
Available Phosphor & 10385,3 & 0 & 4161 \\
Ashes & 1921,13 & 0 & 0 \\
Calcium & 757,88 & 0 & 0 \\
Silicon & 546,38 & 0 & 0 \\
\hline
\end{tabular}

Table XIII. Agent Active Hormones kg/month.

\begin{tabular}{lrrr}
\hline Active Agent & $\begin{array}{c}\text { Survey to } \\
\text { Farmers }\end{array}$ & $\begin{array}{c}\text { Counting of } \\
\text { Packages }\end{array}$ & $\begin{array}{c}\text { Census } \\
\text { to Local } \\
\text { Stores }\end{array}$ \\
\hline Gibberellic acid & 0,38 & 0,17 & 0,03 \\
Acetiltioprolina & 0,002 & 0 & 0 \\
Folic Acid & 0,20 & 0 & 0 \\
\hline
\end{tabular}

Table XIV. Agent Active Adjuvants kg/month.

\begin{tabular}{lrrr}
\hline \multicolumn{1}{c}{ Active Agent } & Survey to Farmers & $\begin{array}{c}\text { Counting of } \\
\text { Packages }\end{array}$ & $\begin{array}{c}\text { Census to } \\
\text { Local Stores }\end{array}$ \\
\hline Alkyl Phenol polyglycol & 20,38 & 3,07 & 27,17 \\
Polysaccharides, polyvinyl alcohols, nonylphenols, & & & \\
silicones & 6,23 & 20,66 & 9,47 \\
Ethanol polyethoxylated nonyl phenol & 12,85 & 3,27 & 28,89 \\
Alcohol ethoxylate & 2,86 & 1,63 & 10,39 \\
Alkyl aryl polyether alcohol, & 0 & 2,81 & 38,38 \\
Alkyl ether polyoxiethylene & 1,90 & 1,09 & 6,92 \\
\hline
\end{tabular}

Interestingly, $76 \%$ of farmers reported they do not rotate crops, and have been using basically the same set of agrochemicals for at least the past 18 years. Likewise, $83 \%$ of farmers have cultivated their land continuously for near 20 years without letting it rest.

\section{Conclusions}

This study characterizes cultivated areas in the surroundings of the Lake of Tota, and identifies the main active ingredients used in agriculture process, as well as their quantities and use frequency. 
From this study it is possible to conclude that:

It is necessary to train farmers in the safe use of agrochemicals, due to the potential health risks they are exposed by mixing chemicals with no regard for their active ingredients and manufacturers' recommendations, and without any technical assistance.

The possible overuse of active ingredients during the mixing of agrochemicals should be evaluated. The mixing of agrochemicals without taking into account their active ingredients may result in the application of much higher doses than the recommended, because the active ingredient may be present in several of the employed products.

It is necessary to conduct, as soon as possible, a physical-chemical study to determine the presence of agrochemicals' active ingredients (found in this study) in the water of the Lake of Tota. Since some of these active ingredients have been reported as potential causes of several diseases (30) to (32), such study will allow determining the potential effect of active ingredients on human health and the environment.

From the results of this study, it can be stated that the amounts and frequencies of use of various of the active agents of the agrochemicals employed in the surroundings of the Lake of Tota exceed in many cases the dose recommended by manufacturers and the environmental authorities. Consequently, there is a high risk of contamination to the soil and water in the study area, which can raise in turn the risk to the health of farmers and consumers of water and green onion produced in this region. Because the importance of this lake and its influence area nationwide, further studies should be conducted to assess the real impact of each of the potential risks identified herein.

\section{Acknowledgements}

This study was partially funded by Dirección de Investigaciones DIN at UPTC through the project SGI-1326. Authors want to thank the collaboration of Professors Jesús Eugenio Vásquez Hurta- do, Jaime Alberto García Sierra, and Rafael Joya Valderrama, who are at UPTC, Faculty Sogamoso.

\section{References}

(1) Conpes 3801 de 2014, Manejo Ambiental Integral de la Cuenca Hidrográfica del Lago de Tota, Consejo Nacional de Política Económica y Social CONPES - Departamento Nacional de Planeación - República de Colombia, Bogotá, D.C. Available: http://portalterritorial.gov.co/ apc-aa-files/40743db9e8588852c19cb285e420affe/conpes-3801.pdf.

(2) Primer Censo del Cultivo de Cebolla Larga, Departamento Administrativo Nacional de Estadística, DANE, 2001. Available: http://www. dane.gov.co/files/investigaciones/agropecuario/enda/ena/Cebolla_Boyaca_Reg_Laguna_ Tota.pdf.

(3) Pinzón Ramírez, H., La cebolla de rama y su cultivo, Fierro Lu Ed., Produmedios, Ed. Tibaitatá, Mosquera, Colombia: Corpoica, Asohofrucol (Online) 2004. Available: http:// conectarural.org/sitio/sites/default/files/documentos/.

(4) WWN Commite (Internet Web Page). Bucarest: World Wetland Network Wetland Globes, (Online) (Accessed on July 2012). Available: http://www.worldwetnet.org/.

(5) Günter, H. Declaración de la Conferencia de las Naciones Unidas sobre el Medio Humano (Declaración de Estocolmo), de 1972, y Declaración de Río sobre Medio Ambiente y Desarrollo, 1992, United Nations Audiovisual Library of International Law, (Online) 2012. Available: http://legal.un.org/avl/pdf/ha/dunche/dunche_s.pdf.

(6) Naciones Unidas, Documento Final de la Conferencia, Conferencia de las Naciones Unidas sobre el Desarrollo Sostenible Rio + 20, Río de Janeiro (Brasil) 20 a 22 de junio de 2012, Río de Janeiro, Brasil, ONU: 1-59 (Online) 2012, Available: https://rio20.un.org/sites/rio20.un.org/files/a-conf.216-I-1_spanish.pdf. 
(7) Decreto 2811 de 1974, Código Nacional de Recursos Naturales Renovables y de Protección al Medio Ambiente, Presidencia de la República de Colombia, Bogotá, D.C. (Diario Oficial No. 34.243, del 27 de enero de 1975). Available: http://www.secretariasenado.gov. co/senado/basedoc/decreto_2811_1974.html.

(8) Decreto 1541 de 1978, Reglamenta la Parte III del Libro II del Decreto-Ley 2811 de 1974: "De las aguas no marítimas" y parcialmente la Ley 23 de 1973 República de Colombia. (Diario Oficial No. 35078 de 21 de agosto de 1978). Ministerio de Agricultura. Available: https://www.minambiente.gov.co/.

(9) Ley 99 de 1993, Ley General Ambiental de Colombia, (Diario Oficial No. 41.146, de 22 de diciembre de 1993) Congreso de la República de Colombia, Bogotá, D.C. Available: http://oab.ambientebogota.gov.co/.

(10) Ley 373 de 1997, Programa para el uso eficiente y ahorro del agua, (Diario Oficial No. 43.058 del 11 de junio de 1997). Congreso de la República de Colombia. Available: http:// www.emdupar.gov.co/.

(11) Corporaciones Autónomas Regionales y Desarrollo Sostenible, Departamento Administrativo de la Función Pública de la República de Colombia, 2010. Available: http://portal.dafp. gov.co/.

(12) China's Water Crisis Part I Introduction, China Water Risk PI, (Online) 2010. p. 13, Available from: http://chinawaterrisk.org/.

(13) China's Water Crisis Part II Water Facts at a Glance, China Water Risk PII (Online) 2010. Available: http://chinawaterrisk.org/.

(14) Charting Our Water Future - Economic frameworks to inform decision-making, The 2030 Water Resources Group (Online) 2009: 1-32. Available: http://www.mckinsey.com/.

(15) Peng X., Chao-yang F., Hong-wen C., Zhigang L., Bin L and Ming-lei F., Establishment of Wa- ter Quality Monitoring Database in Poyang Lake. Procedia Environmental Sciences, 2011; 10: 2581-2586.

(16) Botta F., Lepot B., Leoz-Garziandia E., and Morin A., Estimation of sampling uncertainty in lake-water monitoring in a collaborative field trial. TrAC Trends in Analytical Chemistry, 2012; 36: 176-184. DOI: http://dx.doi. org/10.1016/j.trac.2011.12.007.

(17) McCullough I. M., Loftin C. S., and Sader S. A. High-frequency remote monitoring of large lakes with MODIS 500m imagery, Remote Sensing of Environment, 2012; 124: 234-241. DOI: http://dx.doi.org/10.1016/j. rse.2012.05.018.

(18) Kutser T. The possibility of using the Landsat image archive for monitoring long time trends in coloured dissolved organic matter concentration in lake waters. Remote Sensing of Environment, 2012; 123: 334-338. DOI: http:// dx.doi.org/10.1016/j.rse.2012.04.004.

(19) FAO, Encuestas agrícolas con múltiples marcos de muestreo. Rome, Italy: Roma (Italia). FAO, vol. 1. (Online) 1996. Available: http:// www.fao.org/.

(20) FAO, Encuestas agrícolas con múltiples marcos de muestreo. Rome, Italy: Roma (Italia). FAO, vol. 2. (Online) 1998. Available: http:// www.fao.org/.

(21) Bush J. and House C. The area frame: a sampling base for establishment surveys, in Proceedings of the International Conference on Establishment Surveys, Fairfax, Virginia, USA, 1993, 335-344.

(22) Ferraz C. Improving methods for linking area frames with list frames: literature review preliminary results, Pernambuco, 1-12, (Online) 2013. Available: http://www.fao.org/.

(23) Pérez García A. J. and Macías Acevedo J. P., Plan de Ordenamiento y Manejo de la Cuenca del Lago de Tota Convenio número 038 de 
2004. CORPOBOYACÁ-PUJ. Pontificia Universidad Javeriana, (Online) 2005. Available: http://www.corpoboyaca.gov.co/.

(24) Cordero R. D., Ruiz J. E., and Vargas E. F., Spatial temporal determination of phosphorus concentration in Lake of Tota. Revista Colombiana de Química, 2005; 34(2): 211-218.

(25) Noriega M., Jorge Ari A., Castillo D., Vásquez A., Estudio preliminar del estado de la microcuenca Los Pozos y su posible efecto en un sector de la laguna de Tota, Boyacá, Colombia. Journal of Technology, 2010; 9(2):145164.

(26) Mojica Andrea, Guerrero Jairo A. Evaluación del movimiento de plaguicidas hacia la cuenca del Lago de Tota, Colombia. Revista Colombiana de Química, 2013; 42(2): 29-38.

(27) Rojas LM, Lesmes FC, Rodríguez CJ. Pesticide Flow Analysis in the Tota Lake Watershed in the Boyacá Region in Colombia. Conference paper on Annual International Conferences on Earth, Geology and Geography, pp 48-49, 2015.

(28) Ramírez A. Lizeth N., Torres B. Nixon H., Caracterización de la zona de influencia del cultivo de cebolla larga y la determinación de tasas de usos de los agroquímicos en el Lago de Tota. Universidad Pedagógica y Tecnológica de Colombia, Facultad Seccional Sogamoso, Escuela de Ingeniería Industrial, 2014.

(29) Campolimpio.org., CampoLimpio Web Site. (Online). Available: http://campolimpio.org/.

(30) Mostafalou S. and Abdollahi M., Pesticides and human chronic diseases: evidences, mechanisms, and perspectives, Toxicology and applied pharmacology, 2013; 268(2): 157-177. DOI: http://dx.doi.org/10.1016/j. taap.2013.01.025.

(31) Nordby K., Andersen A., Irgens L. M., and Kristensen P., Indicators of Mancozeb exposure in relation to thyroid cancer and neural tube defects in farmers' families, Scandinavian journal of work, environment \& health, 2005; 31(2): 89-96. DOI: http://dx.doi.org/10.5271/ sjweh.855.

(32) Rasgele P. G., Muranli F. D. G., and Kekecoglu M., Assessment of the genotoxicity of Propineb in mice bone marrow cells using micronucleus assay, Cytology and Genetics, 2014; 48(4): 233-237. DOI: http://dx.doi. org/10.3103/S0095452714040045. 